\title{
Correlation among Sodium Intake, Fat Intake, and Physical Activity with Prevalence of Hypertension in Young Adults at Arifin Achmad Regional Public Hospital, Riau
}

\author{
Annisa Amalia Huzaipah, Evawany Yunita Aritonang, Rahayu Lubis
}

Faculty of Public Health, Universitas Sumatera Utara

\section{ABSTRACT}

Background: Hypertension is called the silent killer for it has high prevalence rate and is asymptomatic; thus, it needs to be early prevented. When blood pressure is high and uncontrollable, it may lead to complications. Today, hypertension is not only found in elderly, it is also found among young adults at age $>18$ and it tends to increase annually as they frequently consume high sodium and high fat and lack of physical activities along with the development of technology. Developed technology has made everything easy to do without burning excessive energy. More researches on hypertension are conducted on elderly and only a few are conducted on young adults. The objective of this study is to discover the correlation among sodium intake, fat intake, and physical activity with prevalence of hypertension in young adults at Arifin Achmad Regional Public Hospital, Riau Province.

Subjects and Method: This is an analytical observational study with case control design that was carried out at Arifin Achmad Regional Public Hospital, Riau Province, Indonesia. A sample of 80 respondents divided into case group with 40 respondents and control group with 40 respondents was selected by purposive sampling. The dependent variable was prevalence of hypertension. The independent variables were sodium intake, fat intake, and physical activity. The instrument used was questionnaires. The data were collected through interviews and analysed by bivariate analysis (chi-square) and multivariate analysis (multiple logistic regression testing).

Results: The results of multivariate test demonstrated that variable sodium intake $(\mathrm{OR}=$ 2.39; $95 \% \mathrm{CI}=0.84$ to $6.75 ; \mathrm{p}=0.099)$ and fat intake $(\mathrm{OR}=2.73$; $95 \% \mathrm{CI}=0.92$ to 8.06 ; $\mathrm{p}=$ o.069) did not show any correlation with prevalence of hypertension because it did not meet the required $p$ value $=<0.05$. The results also showed that prevalence of hypertension physical was most correlated with physical activity $(\mathrm{OR}=4.54 ; 95 \% \mathrm{CI}=1.59$ to $13.00 ; \mathrm{p}=$ 0.005).

Conclusion: There was a significant correlation among sodium intake, fat intake, and physical anctivity with the prevalence of hypertension in the young adults at Arifin Achmad Regional Public Hospital, Riau Province and the most dominant variable was physical activity.

Keywords: sodium, fat, physical activity and prevalence of hypertension

\section{Correspondence:}

Annisa Amalia Huzaipah. Faculty of Public Health, Universitas Sumatera Utara. Jl. Dr. T. Mansur 9, Medan, North Sumatera. Email: annisaamaliahzp@gmail.com. Mobile: 085278296171.

\section{Cite this as:}

Huzaipah AA, Aritonang EY, Lubis R (2020). Correlation among Sodium Intake, Fat Intake and Physical Activity with Prevalence of Hypertension in Young Adults at Arifin Achmad Regional Public Hospital, Riau. J Epidemiol Public Health. 05(03): 384-392. https://doi.org/10.26911/jepublichealth.2020.05.03.12.

(c) (i) (-) Journal of Epidemiology and Public Health is licensed under a Creative Commons EY NC SA Attribution-Non Commercial-Share Alike 4.o International License.

\section{BACKGROUND}

Hypertension was a problem that needed to be taken seriously as its prevalence was high and it tended to occur without syndrome; thus, it was well known as the silent killer of death (Bustan, 2015). World Health 
Organization (2011) predicted an increase in hypertension cases in developing countries based on prevalence of hypertension and an increase in population from nowadays up to eight million people every year and in mortality rate at approximately 1.5 million people in Southeast Asia.

The data from Basic Health Research showed that prevalence of hypertension according to results of interviews in Riau Province was 6\% and according to assessment, itwas 20.9\% (Ministry of Health, 2013). Prevalence of hypertension in Pekanbaru based on assessment was $18.1 \%$ in 2013. In 2016, there were 45,574 hypertension cases out of 6,500,971 people or 0.7\% (Health Agency of Riau Province, 2016).

The data from Health Agency of Pekanbaru (2017) showed that there were 23,885 hypertension cases. It also showed that hypertension cases ranked second from 2014 until 2016 among the other ten diseases with the highest prevalence rate in Pekanbaru with total number of cases from 2014 until 2016 (20,601 cases; 31,437 cases; and 31,396 cases). The data from Health Agency of Riau Province (2013) presented that hypertension ranked second in outpatient treatment among the big ten diseases at all hospitals in Riau Province with 17 thousand cases and ranked fifth in inpatient treatment with 950 cases.

According to the ten big diseasepatterns obtained from the medical record in internal medicine polyclinic at Arifin Achmad Regional Public Hospital, Riau Province, hypertension cases in 2017 ranked sixth with 3,054 cases but inpatient hypertension was not included into the ten big diseases with 89 cases. The number of new hypertension cases from January until October, 2018, was 308 outpatients and the number of young adults among the new outpatients (26-45 years old) from January until October, 2018, was 54 outpatients (17 males and 37 females); whereas the number of inpatient hypertension was 9 inpatients ( 4 males and 5 females). These numbers indicated that hypertension was not necessarily found among old people but also among young adults who were still productive.

The results of previous studies demonstrated that there was correlation among sodium and fat intake with prevalence of hypertension among the elderly (Stefhany, 2012; Mahmudah et al., 2015; Akbar, 2018; Fitri et al., 2018; Salman et al., 2018; Hasiando et al., 2019) and $25.8 \%$ of today's people $\geq 18$ years old suffered from hypertension. The age range of hypertension patients slowly shifted to younger age (18-45 years of age) (Tirtasari and Kodim, 2019). This fact could be a serious health problem as it might disturb activities and caused dangerous complications when it was out of control and no effort was made to prevent it (Sarumaha and Diana, 2018). Hypertension could be prevented from the beginning by having routine blood pressure checkup, especially when one was diagnosed with hypertension, he could prevent complications such as coronary artery disease, heart failure, kidney failure, stroke and retinopathy (Nuraini, 2015; Artiyaningrum and Azam, 2016). Hypertension tends to be resulted from the pile of sodium amount which increases the risk for hypertension, from the high consumption of fatty food which piles cholesterol in blood forming plaques and blood clots that trigger hypertension and from the lack of physical activity that decreases blood vessel elasticity and heart system. This was how blood pressure increased (Kartika et al., 2016).

Nowadays hypertension is not only found in elderly, but it is also found in young adults who are still productive and this trend continues to rise every year. This condition has encouraged the researcher to do research to discover whether the risk factors of 
hypertension such as consumption of high sodium and high fat foods and lacking in physical activity, as today's developed technology has made everything very easy to do even without burning excessive energy, are correlated with prevalence of hypertension. There are more researches on hypertension conducted on elderly and only few are conducted on young adults. Therefore, this research focused on hypertension among young adults. The objective of this research is to discover the correlation among sodium intake, fat intake and physical activity with prevalence of hypertension among young adults at Arifin Achmad Regional Public Hospital in Riau Province.

\section{SUBJECTS AND METHOD}

\section{Study Design}

This was a case control study that was conducted at Arifin Achmad Regional Public Hospital Riau Province, Indonesia, from January 2018 until October 2019.

\section{Population dan Sample}

The population was all hypertension patients and non-hypertension patients at young adulthood (26-45 years of age) at the Internal Medicine Polyclinic and recorded in the medical records in Arifin Achmad Regional Public Hospital, Riau Province. The samples consisted of 40 respondents in case group and 40 respondents in control group with ratio 1:1. There were total 80 respondents taken as the samples. The samples were taken by applying purposive sampling technique.

\section{Study Variables}

The dependent variable in this study was prevalence of hypertension and the independent variables were sodium intake, fat intake and physical activity.

\section{Operational Definition of Variables}

Sodium Intake refers to respondents' frequency in consuming high sodium foods within one last month.

1. Frequent, when score of high sodium food consumption is $\geq$ mean of total scores of all respondents' frequency in consuming high sodium foods.

2. Not frequent, when score of high sodium food consumption is < mean of total scores of all respondents' frequency in consuming high sodium foods.

Fat intake refers to respondents' frequency in consuming high fat foods within one last month.

1. Frequent, when score of high fat food consumption is $\geq$ mean of total scores of all respondents' frequency in consuming high fat foods.

2. Not frequent, when score of high fat food consumption is < mean of total scores of all respondents' frequency in consuming high fat foods.

Physical Activity refers to all kinds of activities which burn energy and are performed by respondents within 24 hours.

1. Mild, when the sum of PAL scores (Physical Activity Level) of respondents' all physical activities in the questionnaires < 1.70

2. Moderate and heavy, when the sum of PAL scores (Physical Activity Level) of respondents' all physical activities $\geq 1.70$

\section{Study Instruments}

Blood pressure was assessed by using Sphygmomanometer and Stethoscope.

Data about sodium intake were obtained by assessment using form of Food Frequency Questionnaires (FFQ) collected through interviews.

Data about fat intake were obtained by assessment using form of Food Frequency Questionnaires (FFQ) collected through interviews. 
Huzaipah et al./ Sodium Intake, Fat Intake, and Physical Activity with Prevalence of Hypertension

Data about physical activity were obtained by assessment using questionnaires collected through interviews.

\section{Data Analysis}

The data in this study were analyzed by a multiple logistic regression.

\section{Research Ethic}

This study applied principles of ethics in its implementation, which provided early approval informed, and implemented principles such as respectful to human dignity, beneficial, not crime, and just. The ethical clearance letter was received from Committee of Research Ethics, University of Sumatera Utara, Indonesia, No. 9896/UN 5.2.1.10/K$\mathrm{RK} / 2018$.

\section{RESULTS}

\section{A. Univariate analysis}

The results of univariate analysis on characteristics of samples demonstrated that females were more prone to hypertension whereas family history showed that majority of hypertension patients had history of hypertension. These results indicated that hypertension patients frequently consumed high sodium and high fat foods and lacked of physical activities compared to those who did not suffer from hypertension. The univariate analysis results are presented in table 1.

\section{B. The result of bivariate analysis}

The bivariate analysis used chi-square test. Table 2 illustrates that sodium intake, fat intake and physical activity are significantly correlated with prevalence of hypertension among young adults at Arifin Achmad Regional Public Hospital, Riau Province. The bivariate analysis results are shown in table 2.

\section{The result of multilevel analysis}

The multivariate analysis used multiple logistic regression test. It is results demonstrated that physical activity was the most significantly correlated with prevalence of hypertension with OR 4.54. The multivariate analysis results are illustrated in table 3 . The Table 3 that the variable with most significant correlation with prevalence of hypertension was physical activity $(\mathrm{OR}=4.54 ; 95 \%$ $\mathrm{CI}=1.59$ to $13.00 ; \mathrm{p}=0.005$ ) which indicated that, lack of physical activity increased 4.54 times higher risk for hypertension.

\section{Table 1. Univariate Analysis}

\begin{tabular}{lcccc}
\hline \multirow{2}{*}{ Independent Variables } & \multicolumn{4}{c}{ Prevalence of Hypertension } \\
\cline { 2 - 5 } & \multicolumn{3}{c}{ Case } & Control \\
\cline { 2 - 5 } Sex & n & \% & \% \\
$\quad$ Males & 16 & 40.00 & 16 & 40.00 \\
$\quad$ Females & 24 & 60.00 & 24 & 60.00 \\
Family History & & & & \\
$\quad$ Hypertension & 32 & 80.00 & 6 & 15.00 \\
$\quad$ Non-Hypertension & 8 & 20.00 & 34 & 85.00 \\
Sodium Intake & & & & \\
$\quad$ Frequently & 27 & 67.50 & 17 & 42.50 \\
$\quad$ Not frequently & 13 & 32.50 & 23 & 57.50 \\
Fat Intake & & & & \\
$\quad$ Frequently & 26 & 65.00 & 17 & 42.50 \\
$\quad$ Not frequently & 14 & 35.00 & 23 & 57.50 \\
Physical Activity & & & & \\
$\quad$ Mild & & 70.00 & 17 & 42.50 \\
$\quad$ Moderate-Heavy & 28 & 30.00 & 23 & 57.50 \\
\hline
\end{tabular}


Huzaipah et al./ Sodium Intake, Fat Intake, and Physical Activity with Prevalence of Hypertension

Table 2. Bivariate Analysis

\begin{tabular}{|c|c|c|c|c|c|c|c|c|}
\hline \multirow[t]{3}{*}{ Variable } & \multicolumn{4}{|c|}{$\begin{array}{l}\text { Prevalence of } \\
\text { Hypertension }\end{array}$} & \multirow{3}{*}{$\mathbf{O R}$} & \multicolumn{2}{|c|}{$95 \% \mathrm{CI}$} & \multirow[t]{3}{*}{$\mathbf{p}$} \\
\hline & \multicolumn{2}{|c|}{ Case } & \multicolumn{2}{|c|}{ Control } & & \multirow[t]{2}{*}{ Lower } & \multirow[t]{2}{*}{ Upper } & \\
\hline & $\mathbf{n}$ & $\%$ & $\mathbf{n}$ & $\%$ & & & & \\
\hline \multicolumn{9}{|l|}{ Sodium Intake } \\
\hline Frequently & 27 & 67.50 & 17 & 42.50 & 2.81 & 1.12 & 6.99 & 0.025 \\
\hline Not frequently & 13 & 32.50 & 23 & 57.50 & & & & \\
\hline \multicolumn{9}{|l|}{ Fat Intake } \\
\hline Frequently & 26 & 65.00 & 17 & 42.50 & 2.51 & 1.01 & 6.19 & 0.044 \\
\hline Not frequently & 14 & 35.00 & 23 & 57.50 & & & & \\
\hline \multicolumn{9}{|l|}{ Physical Activity } \\
\hline Mild & 28 & 70.00 & 17 & 42.50 & 3.15 & 1.25 & 7.93 & 0.013 \\
\hline Moderate-Heavy & 12 & 30.00 & 23 & 57.50 & & & & \\
\hline
\end{tabular}

Table 3. Multivariate Analysis

\begin{tabular}{|c|c|c|c|c|}
\hline \multirow[b]{2}{*}{ Independent Variables } & \multirow[b]{2}{*}{$\mathbf{O R}$} & \multicolumn{2}{|c|}{ 95\% CI } & \multirow[b]{2}{*}{$\mathbf{p}$} \\
\hline & & $\begin{array}{c}\text { Lower } \\
\text { limit }\end{array}$ & $\begin{array}{c}\text { Upper } \\
\text { limit }\end{array}$ & \\
\hline Sodium Intake & 2.39 & 0.84 & 6.75 & 0.099 \\
\hline Fat Intake & 2.73 & 0.92 & 8.06 & 0.069 \\
\hline Physical Activity & 4.54 & 1.59 & 13.00 & 0.005 \\
\hline \multicolumn{5}{|l|}{$\mathrm{N}$ observation $=80$} \\
\hline \multicolumn{5}{|l|}{$-2 \log$ likelihood= $109.621^{\mathrm{a}}$} \\
\hline 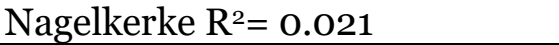 & & & & \\
\hline
\end{tabular}

\section{DISCUSSION}

\section{Characteristics of samples}

The results of this study demonstrated that the subject was 80 respondents consisting of 40 hypertension patients (50\%) and 40 non hypertension patients (50\%). The risk for hypertension significantly increased in females compared to in males. It was possibly caused by the effect of hormone. Estrogen contributed to differences in gender to control blood pressure (Pikir et al., 2015).

The hypertension patients at Arifin Achmad Regional Public Hospital, Riau Province consisted of more females than males. It was in line with the results of Basic Health Research which showed that prevalence of hypertension among women was higher than among males (Ministry of Health, 2013). The distribution of respondents based on their family history showed that the respondents suffering from hypertension had history of more prevalence of hypertension in their family than those who did not have history of hypertension.

\section{Correlation between sodium intake} and prevalence of hypertension

Table salt contains sodium required by body to perform its functions. It should not be consumed excessively because continuous excessive salt intake will lead to hypertension. WHO suggested sodium intake limit at 2,400 $\mathrm{mg}$ per day (equal with 6 gram of table spoons) and consumption of potassium-high foods such as fruits and vegetables at the same time (Fauziah et al., 2013).

The results of chi-square test demonstrated that there was a significant correlation between sodium intake and prevalence of hypertension in young adulthood at Arifin Achmad Regional Public Hospital, Riau Province. The respondents 
were interviewed concerning their frequency in sodium-high ingredient consumption such as sources of carbohydrate (cakes, sandwiches, white bread, and instant noodle), animal side dishes (salted fish and prawns), milk (cream milk powder), ketchup, sauce, and seasonings in the past month. The hypertension respondents' sodium intake frequency was categorized into frequently if the mean was $\geq 2.39$; and it was categorized into not frequently if the mean was $<2.39$. Meanwhile, the non-hypertension respondents' sodium intake frequency was categorized into frequently if the mean was $\geq$ 2.23 and it was categorized into not frequently if the mean was $<2.23$.

The results of interviews with respondents using forms of Food Frequency Questionary (FFQ) obtained (OR=2.81; 95\% $\mathrm{CI}=1.12$ to $6.99 ; \mathrm{p}=0.025)$. It indicated that one who frequently consumed high-sodium foods was at 2.81 times higher risk for hypertension. This result was in line with the study conducted by Atun et al. (2014) stating that excessive sodium intake increased 5.70 times higher risk for hypertension with OR 5.70 (95\% CI= 1.51 to $21.42 ; \mathrm{p}=0.016$ ), the study by Montol et al. (2015) finding out that excessive sodium intake increased 9.20 times higher risk for hypertension with OR 9.20 $(\mathrm{p}=0.001)$ and the study by Salman et al. (2015) discovering that excessive sodium intake increased 5.63 times higher risk for hypertension with OR 5.63 (95\% CI= 2.20 to 14.43; $\mathrm{p}=<0.001$ ).

\section{Correlation between fat intake and prevalence of hypertension}

Excess body fat creates risks for arteriosclerosis. Arteriosclerosis or hardening of arteries may decrease artery elasticity because fat clogs blood flow in arteries so that increases blood pressure and triggers hypertension. Limiting fat consumption to control blood cholesterol to be not too high could be done by having low fat diet (Savitri, 2017).

The results of chi-square test demonstrated that there was a significant correlation between fat intake and prevalence of hypertension in young adulthood at Arifin Achmad Regional Public Hospital, Riau Province. The respondents were interviewed concerning their frequency in fat-high ingredient consumption such as animal side dishes (chicken meat with skin, beef, lamb, and innards), milk (ice cream), coconut milk and fries in the past month. The hypertension respondents' fat intake frequency was categorized into frequently if the mean was $\geq$ 1.71; and it was categorized into not frequently if the mean was $<1.71$. Meanwhile, the non-hypertension respondents' fat intake frequency was categorized into frequently if the mean was $\geq 1.68$ and it was categorized into not frequently if the mean was $<1.68$. The results of interviews with respondents using forms of Food Frequency Questionary (FFQ) obtained ( $\mathrm{OR}=2.51 ; 95 \% \mathrm{CI}=1.01$ to $6.19 ; \mathrm{p}=0.044)$. It indicated that one who frequently consumed high sodium foods was at 2.51 times higher risk for hypertension.

This result was in line with the study conducted by Mardani et al. (2011) stating that excessive fat intake increased 1.98 times higher risk for hypertension with OR 1.98 (95\% CI=1.07 to 3.67; $\mathrm{p}=0.041$ ), the study by Kartika et al. (2016) finding out that excessive fat intake increased 3.83 times higher risk for hypertension with OR 3.83 (95\% CI $=1.35$ to $10.86 ; \mathrm{p}=0.009$ ) and another study discovering that excessive fat intake increased 3.33 times higher risk for hypertension with OR 3.33 (95\% CI= 1.10 to 10.83) (Oktavia and Martini, 2016).

\section{Correlation between physical acti-} vity and prevalence of hypertension Every limb that moved using power and energy was called physical activity (Triyanto, 2014). Lack of physical activity might result 
in less elastic blood vessel which led to blood clots and hypertension (Pikir et al., 2015). The heaviness of physical activity performed by one in 24 hours is stated in physical activity level (PAL). PAL is the amount of energy used in kkal per kilogram body mass in 24 hours. There are some categories in heaviness of physical activity, namely mild category (with PAL $<1.70$ ), moderate to heavy level (with PAL $\geq 1.70$ ). Mild physical activity only required little energy, moderate physical activity required continuous energy, rhythmic muscle movement or flexibility and heavy physical activity required power and was usually related to sports (Stefhany, 2012).

The results of chi-square test demonstrated that there was a significant correlation between physical activity and prevalence of hypertension in young adulthood at Arifin Achmad Regional Public Hospital, Riau Province. The respondents were interviewed with 17 questions about their physical activities in the past 24 hours. The results was $(\mathrm{OR}=3.15 ; 95 \% \mathrm{CI}=1.25$ to 7.93; $\mathrm{p}=0.013$ ). It indicated that one who had mild physical activities was at 3.15 times higher risk for hypertension.

This result was in line with the study conducted by Aripin et al. (2015) stating that if one only performed mild physical activity of had less physical activity, it increased 24.89 times higher risk for hypertension with OR 24.89 (95\% CI= 4.91 to $149.31 ; \mathrm{p}=0.001$ ), the study by Indayani et al. (2016) finding out that there was a significant correlation between physical activity and prevalence of hypertension $(\mathrm{p}=<0.001)$ and a study by Amalia et al. (2017) which discovered similar results stating that there was a significant correlation between physical activity and prevalence of hypertension $(\mathrm{p}=0.001)$, and another study discovering that lack of physical activity increased 2.67 times higher risk for hypertension with OR 2.67 (95\%
$\mathrm{CI}=1.22$ to $5.81 ; \mathrm{p}=0.021$ ) (Litaay and Talarima, 2016).

\section{The factor with the most significant correlation with prevalence of hypertension}

The table of multivariate analysis illustrated that the variable with most significant correlation with prevalence of hypertension was physical activity $(\mathrm{OR}=4.54 ; 95 \% \mathrm{CI}=1.59$ to $13.00 ; \mathrm{p}=0.005$ ) which indicated that, based on the multivariate analysis results using multiple logistic regression test, lack of physical activity increased 4.54 times higher risk for hypertension. It was in line with the study by Widyartha et al. (2016) showing that one who did mild physical activities or lacking of physical activity was at 3.53 times higher risk for hypertension with OR 3.53 (95\% CI $=1.38$ to $9.01 ; \mathrm{p}=<0.001$ ) and another study finding out that lack of physical activities increased 10.06 times higher risk for hypertension with OR 10.06 (95\% CI= 3.2 to 34.5) (Oktavia and Martini, 2016).

It was concluded that, based on the results of multivariate analysis using multiple logistic regression testing, variables of sodium intake $(\mathrm{OR}=2.39 ; 95 \% \mathrm{CI}=0.84$ to 6.75; $\mathrm{p}=0.099)$ and fat intake $(\mathrm{OR}=2.73$; 95\% CI=0.92 to 8.06; $\mathrm{p}=0.069)$ did not show any correlation with prevalence of hypertension as it did not meet the required $\mathrm{p}$ value $=<0.05$ and that prevalence of hypertension was most correlated with physical activity $(\mathrm{OR}=4.54 ; 95 \% \mathrm{CI}=1.59$ to 13.00; $p=0.005$ ). This research was limited to only analyze sodium intake, fat intake and physical activity in spite of many other risk factors of hypertension among young adults. It is suggested that future researchers do further researches on the other risk factors.

\section{AUTHOR CONTRIBUTION}

Annisa Amalia Huzaipah formulated the concepts, collected the data and processed 
Huzaipah et al./ Sodium Intake, Fat Intake, and Physical Activity with Prevalence of Hypertension

study data. Annisa Amalia Huzaipah, Evawany Yunita Aritonang and Rahayu Lubis contributed in designing research methodlogies, collected the data, analyzed the data results and interpreted them.

\section{CONFLICT OF INTEREST}

There was not any conflict of interest in this study.

\section{FUNDING AND SPONSORSHIP}

This study was supported by Prof. Dr. Ir. Evawany Yunita Aritonang, M.Si and dr. Rahayu Lubis, M.Kes., Ph.D.

\section{ACKNOWLEDGEMENT}

The researcher would like to express gratitude to all respondents involved in this study, Director of Arifin Achmad Regional Public Hospital, Riau Province and all staffs, Head of Health Agency of Riau Province and staffs, and Head of Health Agency of Pekanbaru and staffs for the opportunity to accomplish this study.

\begin{tabular}{lll}
\multicolumn{3}{c}{ REFERENCE } \\
Akbar H & (2018). Epidemiological
\end{tabular}
determinants of prevalence of hypertenison in the Working Area of Puskesmas Jatisawit. Hibualamo (Health and Natural Science Series), 2(2): 41-47. Retrieved from https://journal.unhena.ac.id/index.php /hibualamo/article/view/85

Amalia IS, Ismayati, Sobirin A (2017). Analysis of risk factors of prevalence of hypertension in Puskesmas Pamitran, Cirebon, in 2017. Journals of Health Sciences of Bhakti Husada Kuningan, 6(2): 42-49. Retrieved from file://C:/Users/TOSHIBA/Downloads /52-Article\%2oText-77-1-1020180714.pdf

Aripin AAS, Sawitri, Adiputra N (2015). The risk factors of prevalence of hypertension among adults in Banyuwangi. Public Health and Preventive Medicine Archive, 3(2): 141149.

http://dx.doi.org/10.15562/phpma.v3i 2.101

Artiyaningrum B, Azam M (2016). The factors correlated with prevalence of uncontrolled hypertension among patients having routine check up. Public Health Perspective Journal, 1(1): 12-20. Retrieved from https://journal.unnes.ac.id/nju/index. $\mathrm{php} / \mathrm{phpj} /$ article/view/7751

Atun L, Siswati T, Kurdanti W (2014). Sodium source intake, potassiumsodium ratio, physical activities and hypertension patients. MGMI (Indonesian Micro Nutrient Media), 6(1): 63-71. Retrieved from http://ejournal.litbang.kemkes.go.id/in dex.php/mgmi/article/view/3780

Bustan N (2015). Management of noncommunicable disease control. Jakarta: Rineka Cipta.

Health Agency of Riau Province (2013). Health Profile of Riau Province. Retrieved from https://www.depkes.go.id/resources/d ownload/profil/PROFIL_KES_PROVI NSI_2013/O4_Prov_Riau_2013.pdf

Health Agency of Riau Province (2016). Health Profile of Riau Province. Retrieved from https://www.depkes.go.id/resources/d ownload/profil/PROFIL_KES_PROVI NSI_2013/O4_Prov_Riau_2016.pdf

Health Agency of Pekanbaru (2017). P Health Profile of Riau Province. Retrieved from https://www.depkes.go.id/resources/d ownload/profil/PROFIL_KES_PROVI NSI_2013/O4_Prov_Riau_2017.pdf

Fauziah NY, Bintanah S, Handarsari E (2013). Patterns of consumption of 
Huzaipah et al./ Sodium Intake, Fat Intake, and Physical Activity with Prevalence of Hypertension

sodium sources among hypertension outpatients in Rumah Sakit Tugurejo Semarang. Journal of Nutrition of Universitas Muhammadiyah Semarang, 2(1): 1-8. https://doi.org/10.26714/jg.2.1.2013.\% 25

Fitri Y, Rusmikawati, Zulfah S, Nurbaiti (2018). Sodium and potassium intake as the causative factor of hypertension among elderly. AcTion Journal, 3(2): 158-163. https://doi.org/ 10.30867/action.v3i2.117

Hasiando CN, Amar MI, Fatmawati I (2019). The correlation among habit of sodium intake, fat and dureation of sleep among elderly in Puskesmas Cimanggis, Depok, in 2018. Journal of Public Health Sciences, J11(2): 214-218. Retrieved from https://jikm.upnvj.ac.id/index.php/ho $\mathrm{me} /$ article/view/27

Indayani S (2016). The risk factors of prevalence of hypertension in the working area of Puskesmas Tanjung Kemuning, Kaur Regency, in 2016 (An Undergraduate thesis at Dehasen College of Health Science). Retrieved from

http://repository.unived.ac.id/53/1/S\% 2OSUTRI\%2OPDF.pdf

Kartika LA, Afifah E, Suryani I (2016). Fat intake and physical activities and their correlation with prevalence of hypertension among outpatients. Indonesian Journal of Nutrition and Dietetics, $\quad 4(3)$ : $\quad$ 139-146. http://dx.doi.org/10.21927/ijnd.2016.4 (3).139-146

Litaay BP, Talarima B (2016). The risk factors of prevalence of hypertension among patients in internal medicine wards at RSUD Dr. M. Haullusy Ambon. Global Health Science, 1(2):
66-74.

http://dx.doi.org/10.33846/ghs.vii2.32 Mahmudah S, Maryusman T, Arini FA, Malkan I (2015). The correlation among lifesyle and eating pattern with prevalence of hypertension among the elderly in Kelurahan Sawangan Baru, Depok, in 2015.. Biomedika, 7(2): 43510.

https://doi.org/10.23917/biomedika.v8 i2.2915

Mardani S, Gustina T, Dewanto $\mathrm{H}$, Priwahyuni Y (2011). The correlation among Body Mass Index and fat intake habit with blood pressure. Journal of Health Community, 1(3): 129-135. Retrieved from https://jurnal.htp.ac.id/index.php/kes $\mathrm{kom} /$ article/download/17/13

Ministry of Health (2013). Report of Basic Health Research Results (Riskesdas) Indonesia in 2013. Basic Health research of 2013. Jakarta: National Institute of Health Research and Development of the Ministry of Health of Republic of Indonesia.

Montol AB, Pascoal ME, Pontoh L (2015). The risk factors of prevalence of hypertension among productive agedpatients in the Working Area of Puskesmas Lansot, Tomohon. Gizido, 7(1): 1-10. Retrieved from file://C:/Users/TOSHIBA/Downloads /59-Article\%2oText-110-1-1020180320.pdf

Nuraini B (2015). Risk factors of hypertension. J. Majority (Medical Journal of Lampung University), 4(5): 10-19. Retrieved from https://juke.kedokteran.unila.ac.id/ind ex.php/majority/article/view/602

Oktavia F, Martini S (2016). The risk for prevalence of hypertensino based on behavioral factor among Indonesian National Army. Journal of MKMI 
Huzaipah et al./ Sodium Intake, Fat Intake, and Physical Activity with Prevalence of Hypertension

(Indonesian Public Health Media), 12(3): $\quad$ 127-136. https://journal.unhas.ac.id/index.php/ $\mathrm{mkmi} /$ article/view/1067

Pikir BS, Aminuddin M, Subagjo A, Dharmadjati BB, Suryawan IGR, Eko JN (2015). Hypertension. Surabaya: Airlangga University Press.

Salman Y, Anwar R, Jurkessia AM (2015). Sodium and fat consumption pattern as the risk factor of hypertension in the Working Area of Puskesmas Kandangan, Kandangan Sub-district, Hulu Sungai Selatan Regency. Jurkessia (Indonesian Health Journal), 5(2): 1-7. Retrieved from https://journal.stikeshb.ac.id/index.ph $\mathrm{p} /$ jurkessia/article/view/51

Salman Y, Sari M, Libri O (2018). Analysis of dominant factors of prevalence of hypertension among the lelderly at Puskesmas Cempaka. Journal of Nutrition World, 3(1): 15-22. Retrieved from

http://ejournal.helvetia.ac.id/index.ph p/jdg/article/view/4640/359

Sarumaha EK, Diana VE (2018). The risk factors of hypertension among young adults in UPTD Puskesmas of Plus Treatment of Teluk Dalam, Nias Selatan Regency. lobal health Journal, 1(2): 1-8. Retrieved from http://ejournal.helvetia.ac.id/index.ph $\mathrm{p} / \mathrm{jkg} /$ article/view/3914/97

Savitri D (2017). Silent but deadly, prevent gout and hypertension. Yogyakarta: Healthy.

Stefhany E (2012). The correlation among eating pattern, lifestyle and body mass index with hypertension among pre- elderly and elderly at Posbindu Kelurahan Depok Jaya in 2012 (An undergraduate thesis, Universitas Indonesia). Retrieved from http://lib.ui.ac.id/file?file=digital/2031 9769-S-PDF-Emerita\%20\%2 oStefhany.pdf

Tirtasari S, Kodim M (2019). Prevalence and characteristics of hypertension among the young adults in Indonesia. Tarumanegara Medical Journal, 1(2): 395-402. http://dx.doi.org/10.24912/tmj.v1i2.38 51

Triyanto E (2014). Integrated nursing Service for hypertension patientrs. Yogyakarta: Graha Ilmu.

Widyarta MJ, Putra IWGAE, Ani LS (2016). Family medical history, stress, mild physical activity, obesity and eating too salty food as the risk factors of hypertension. Public Health and Preventive Medicine Archive, 4(2): 18614.

https://doi.org/10.15562/phpma.v4i2.7 3

World Health Organization (2011). Health Information. World Health Organization. Retrieved from https://www.depkes.go.id/resources/d ownload/pusdatin/profil-kesehatan indonesia/profil-kesehatan-indonesia2011.pdf 